\title{
Heavy Metals Removal from Swine Wastewater Using Constructed Wetlands with Horizontal Sub-Surface Flow
}

\author{
Jorge A. Cortes-Esquivel ${ }^{1}$, Germán Giácoman-Vallejos ${ }^{1 *}$, Icela D. Barceló-Quintal ${ }^{2}$, \\ Roger Méndez-Novelo ${ }^{1}$, María C. Ponce-Caballero ${ }^{1}$ \\ ${ }^{1}$ Facultad de Ingeniería, Universidad Autónoma de Yucatán, Mérida, México; ${ }^{2}$ Departamento de Ciencias Básicas, Universidad \\ Autónoma Metropolitana, Unidad Azcapotzalco, México, D.F., México. \\ Email: "giacoviera@hotmail.com
}

Received June $15^{\text {th }}, 2012$, revised July $12^{\text {th }}, 2012$; accepted August $10^{\text {th }}, 2012$

\begin{abstract}
The removal efficiency of $\mathrm{Cu}$ and $\mathrm{Zn}$ from swine wastewater was evaluated as effected by three variables: the hydraulic retention time (HRT) (24, 48, 72 and 96 hours), two different plant species (Typha domingensis Pers. and Eleocharis cellulosa) and two different sizes of filter media $(5$ and $15 \mathrm{~mm}$ ) using a horizontal sub-surface flow constructed wetland. From the results, a significant difference was observed in the removal efficiency of $\mathrm{Cu}$ and $\mathrm{Zn}$ with respect to different hydraulic retention times. The best results were obtained in the HRT of 96 hours for $\mathrm{Zn}$ where $96 \%$ removal of $\mathrm{Zn}$ with Typha domingensis Pers. specie with gravel of $15 \mathrm{~mm}$ (experimental unit 6) was achieved. For $\mathrm{Cu}$, at 72 hours of HRT, the efficiency was nearly $100 \%$ in five of the six study units $(1,2,3,5$ and 6). In contrast, in experimental unit 4 with gravel of $15 \mathrm{~mm}$ and without plants, only $86 \% \mathrm{Cu}$ removal was achieved.
\end{abstract}

Keywords: Swine Wastewater; Typha domingensis Pers.; Eleocharis cellulosa; Heavy Metals; Constructed Wetlands; Horizontal Sub-Surface Flow

\section{Introduction}

Quality water is primordial for life. In Mexico, the aquifer resource is scarce and drinking water is expensive. That implies the necessity to carry out regulatory actions in order to protect this resource. Water can be exposed to many forms of contamination, mainly by anthropogenic sources such as domestic, industrial, and agricultural. Among animal activities developed in the country, swine production is important. It generates direct $(49,000)$ and indirect $(245,000)$ employees [1].

The state of Yucatan occupies fifth place at a national level in pig production with 128,979 tons yearly (DWT) [2]. According to Méndez et al. [3], there are 470 pig farms in the state, classified by the Agricultural Ministry (SAGARPA) as 393 small, 27 medium, 40 big and 10 mega. Drucker et al. [4] and Mendez et al. [3] estimate that the daily generated wastewater from local swine farms is in the range of $17-62$ liters per animal weight unit (100 kg live weight per pig per day). That makes a total amount of 3385 tons of solids and a range of 9428 $\mathrm{m}^{3} / \mathrm{d}$ to $16,700 \mathrm{~m}^{3} / \mathrm{d}$ of swine wastewater.

It must be taken into account that the number of confined animals rose on farms and they need to be supple-

${ }^{*}$ Corresponding author. mented with formulated diets to achieve the necessary nutrients in accordance to their growth periods. These elements include heavy metals (HMs) like $\mathrm{Zn}$ and $\mathrm{Cu}$ in the pig diets [5]. Wastewater discharges containing high concentrations of organic material, pathogens and heavy metals become a source of dangerous contamination [6]. These toxic contaminants can filter easily into the groundwater in limestone soils with fractures and fissures which present high permeability as occurs in Yucatan State [7]. On average these swine wastewaters show the following values: COD $32612.20 \mathrm{mg} / \mathrm{L}$, BOD $5496.03 \mathrm{mg} / \mathrm{L}$, fats and oils $550.10 \mathrm{mg} / \mathrm{L}$, TSS $7554.80 \mathrm{mg} / \mathrm{L}$, TKN 880.75 $\mathrm{mg} / \mathrm{L}$ and TP $18.69 \mathrm{mg} / \mathrm{L}$ [8].

The increased concentration of chemical products in certain places produces bioaccumulation in organisms [9] with the consequent poisoning risk for the environment and in links of the food chain. This problem is aggravated by the lack of or ineffective swine wastewater treatment.

Different technologies to remove contaminants from wastewater have been proved worldwide. Constructed wetlands (CWs) have been employed for a variety of purposes, from the rehabilitation of contaminated areas or more specific functions such as the treatment of domestic, storm water, agricultural and industrial wastewa- 
ters [10]. Initially they were employed for the degradation of organic substances and nutrients [11-13] subsequent to the removal of pathogens [14]. In recent years they have been employed for the removal of toxic pollutants such as HMs $[15,16]$, mainly from industrial wastewater.

Different types of CWs are currently in operation, ranging from free water surface (FWS) over horizontal sub-surface flow (HSSF) to vertical sub-surface flow (VSSF) and combinations of these types.

Several encouraging results have been reported from the use of different types of CWs. For instance, according to Vymazal and Kröpfelová [16], the FWS wetlands have been employed primarily to treat wastewater with high concentrations of HMs because the metals precipitate in aerated water as oxides, hydroxides and oxyhydroxides. In contrast, wetlands with HSSF, found mainly in anoxic/anaerobic conditions, remove the metals by precipitation as sulfides. Other ways, Lim et al. [17] have worked in Malasia with a small HSSF-CW to remove trace metals, reporting a removal efficiency of over $99 \%$ for $\mathrm{Cd}, \mathrm{Pb}$ and $\mathrm{Zn}$. In addition, Kröpfelová et al. [18], applying three HSSF-CWs for trace metal removal from municipal wastewater, got on average $78 \%$ removal of $\mathrm{Zn}$ and $50 \%-75 \%$ of $\mathrm{Cu}$ and $\mathrm{Cd}$. It has been determined that the removal processes of contaminants in wetlands are physical, chemical and biological. These affect the mobilization-immobilization of metals [19].

The main physical process in the removal of HMs in natural and CWs is sedimentation [20]. According to Gambrell [21], soil texture and ratio of sand, silt and clay are very important for the immobilization of HMs. The fine-grained sediment containing a significant amount of organic matter tends to accumulate metals, in contrast to a coarse texture filter media which has a low affinity to accumulate metals.

The chemical removal processes include adsorption, absorption, oxidation, hydrolysis, precipitation, co-precipitation and involve some inorganic chemicals such as carbonates and sulfides. Wetlands with a suitable substrate promote the growth of sulfate reducing bacteria (SRB) which are found in anaerobic conditions. These bacteria produce hydrogen sulfide and many HMs can react with hydrogen sulfide to form metal sulfides which are highly insoluble, such as $\mathrm{CuS}, \mathrm{ZnS}, \mathrm{NiS}, \mathrm{PbS}$ [19].

Finally, the assimilation of metals by plants is the main biological process and perhaps is the most important means of removing HMs from wetlands. Plants are involved in the entry of oxygen into the root zone (rhizosphere) which allows the assimilation of nutrients and direct degradation of pollutants [22]. Therefore, plant species in a constructed wetland could play an important role in removal of HMs from wastewater.

These results indicate that the use of constructed wet- lands is an alternative for the treatment of wastewater from the swine industry. Hence, the objective of this study was to evaluate the effect of plant species, filter media and hydraulic retention time (HRT) with respect to the removal of $\mathrm{HMs}, \mathrm{Cu}$ and $\mathrm{Zn}$, from wastewater of the pig sector using a system of HSSF-CW to reduce the negative impact generated by these metals in the environment.

\section{Materials and Methods}

\subsection{Experimental Design Applied in the Constructed Wetlands}

Six experimental units (EUs), in small scale, were constructed at Faculty of Engineering, Autonomous University of Yucatan, located in Yucatan, Mexico (N21 $02^{\prime}$ $\left.56.40^{\prime \prime}, \mathrm{W} 89^{\circ} 38^{\prime} 34.52^{\prime \prime}\right)$. Their dimensions were $2.10 \mathrm{~m}$ long, $0.60 \mathrm{~m}$ deep, $0.70 \mathrm{~m}$ wide and the volume of gravel was $0.37 \mathrm{~m}^{3}$ for each EU. The inlet volume of wastewater in each unit was $150 \mathrm{~L}$ for each different HRT: 24,48 , 72 and 96 hours (Table 1). After every HRT employed, the total volume treated was removed and these units were operating like batch systems.

\subsection{Collection of Plant Species and Acclimatization}

Both species of plants were collected from an artificial lagoon named "Acuaparque" in Merida, Yucatan, Mexico, trying to favor the use of plants of this local region. $150 \mathrm{~L}$ of natural water was added to each experimental unit in order to gain acclimatization after collection. Every other day, the total amount $(150 \mathrm{~L})$ of natural water was gradually replaced by $10 \%, 20 \%, 30 \%$, etc., of swine wastewater until reaching $100 \%$ of this wastewater by the first month. After that time, the nutrition of the plants was gotten only by using swine wastewater maintaining the total volume of $150 \mathrm{~L}$ per unit. The acclimatization time of plants was determined to be when the plants were green, growing and with the presence 60 plants per experimental unit. These qualitative parameters

Table 1. Experimental design applied in the constructed wetlands.

\begin{tabular}{cccc}
\hline EU & Plant species & Filter media & HRT (hours) \\
\hline 1 & Eleocharis $c$. & Fine gravel $(5 \mathrm{~mm})$ & $24,48,72$ and 96 \\
2 & Typha d. & Fine gravel $(5 \mathrm{~mm})$ & $24,48,72$ and 96 \\
3 & Without plants & Fine gravel $(5 \mathrm{~mm})$ & $24,48,72$ and 96 \\
4 & Without plants & Coarse gravel $(15 \mathrm{~mm})$ & $24,48,72$ and 96 \\
5 & Eleocharis $c$. & Coarse gravel $(15 \mathrm{~mm})$ & $24,48,72$ and 96 \\
6 & Typha d. & Coarse gravel $(15 \mathrm{~mm})$ & $24,48,72$ and 96 \\
\hline
\end{tabular}


were observed to be achieved at three months.

\subsection{Analytical Procedures}

$1 \mathrm{ppm}$ of the metal to be analyzed was added to each sample so that the sample concentration was in the optimum detection level of the employed spectrophotometer (atomic absorption with flame detection from Varian trademark, model 240FS). The standard addition technique was taken into account since the result contained the amount added (fixed concentration) plus the amount of the original sample.

The relation of nitric acid $\left(\mathrm{HNO}_{3}\right)$ and perchloric acid $\left(\mathrm{HClO}_{4}\right)$ was $6: 1$ during the digestion of the samples and the concentration of $\mathrm{Zn}$ and $\mathrm{Cu}$ was determined by applying the method for air-acetylene flame atomic absorption spectrophotometry according to Standard Methods [23].

\subsection{Characterization}

In order to know the variability of $\mathrm{HMs}(\mathrm{Cu}$ and $\mathrm{Zn})$ in the swine wastewater generated daily on the farm, the characterization was carried out during nine days (Mondays, Tuesdays and Thursdays) in a period of three weeks. The analysis during characterization of $\mathrm{Cu}$ and $\mathrm{Zn}$ was determined by applying the method for air-acetylene flame atomic absorption spectrophotometry.

\subsection{Sampling}

The monitoring time for this study was during the months of January to April 2010, corresponding to the dry season. The residual water was taken from the main sump, which contains the total daily generated volume of wastewater on the farm.

One day before starting the experimental sampling for each HRT in wetlands, around $1000 \mathrm{~L}$ of swine wastewater was collected. This wastewater was put into two settling tanks to separate thick solids over a 24 hour period. After this time, each experimental unit was filled with $150 \mathrm{~L}$.

The sample volume for laboratory analysis of the input (influent) and output (effluent) line was 1 liter per unit. The input sample was taken from the output current of the settling tanks at intervals of approximately $200 \mathrm{~mL}$. The effluent sampling was done similarly to that of the influent with variation of the partially opened discharge valve in order to prevent a drag on the biofilm support. The heavy metal analyses were performed using the same analytical technique employed in the characterization.

\subsection{Statistical Analysis}

Statistical analysis was carried out using the Statgraphics
Plus 5.1 software. Since the HMs concentration values in the influent and effluent were not normally distributed, the nonparametric Kruskal-Wallis test according to Montgomery [24] was applied.

\section{Results and Discussion}

\subsection{Characterization}

Comparing the HMs results in swine wastewater obtained in the present study during it is characterization with the Mexican Official Standard (NOM-001-ECOL1996) [25], five of the nine results for $\mathrm{Zn}$ and $\mathrm{Cu}$ were found to be above the permitted limit (10 and $4 \mathrm{mg} / \mathrm{L}$, respectively). The highest $\mathrm{HM}$ concentration found in this work was $327 \mathrm{mg} / \mathrm{L}$ for $\mathrm{Zn}$ and $5.14 \mathrm{mg} / \mathrm{L}$ for $\mathrm{Cu}$. That shows a wide variability of HMs concentration that is being discharged in swine wastewater with a high negative impact for the environment. Table 2 shows that the concentration of $\mathrm{Cu}$ and $\mathrm{Zn}$ in this study was higher than in other studies which used a different wastewater.

As shown in Table 2, information is scarce about the CWs employed in treatment of HMs in swine wastewater because most CWs are employed to treat organic substances, nutrients and pathogens in swine wastewater $[29,30]$.

\subsection{Removal Efficiencies of Zn}

The results in Figure 1 show the obtained removal of $\mathrm{Zn}$ in each of the experimental units considering the combination of different factors like type of plant species, different size of filter media, and the HRT employed.

It was observed that in the 24 hour HRT, the best $\mathrm{Zn}$ removal achieved in units 1, 2, 5 and 6 was $89 \%$ and the lowest removal observed was in unit 3 (considered as control with fine gravel support media (FG) and without plants) with $79 \%$.

The decreased removal percentage observed in the 48

Table 2. Comparison between the average inlet concentrations of HMs in this study with the concentrations obtained by other authors.

\begin{tabular}{cccc}
\hline \multirow{2}{*}{ Reference } & Wastewater & \multicolumn{2}{c}{ Inlet concentration $(\mathrm{mg} / \mathrm{L})$} \\
\cline { 3 - 4 } & & $\mathrm{Cu}$ & $\mathrm{Zn}$ \\
\hline Maine et al. [26] & Industrial $^{\mathrm{a}}$ & $\mathrm{N} . \mathrm{d}^{\mathrm{c}}$ & 0.06 \\
Lesage et al. [27] & Domestic $_{\text { }}$ & 0.02 & 0.13 \\
Kröpfelová et al. [18] & Domestic & 0.03 & 0.16 \\
Yeh et al. [28] & Swine & 0.64 & 0.37 \\
This study & Swine & 3.10 & 54 \\
\hline
\end{tabular}

${ }^{\mathrm{a}}$ Metallurgic Industry; ${ }^{\mathrm{b}}$ River water contaminated by confined swine operations; ${ }^{\mathrm{c}}$ Not determined. 


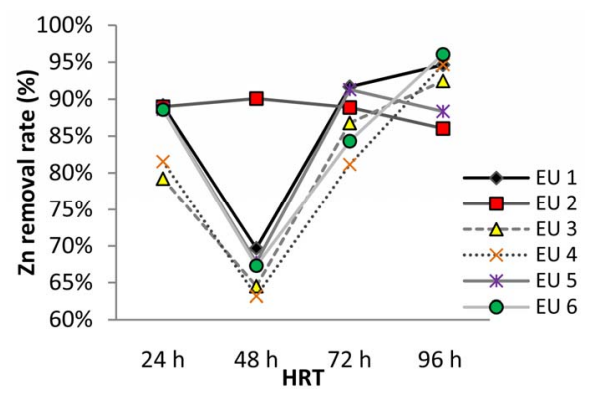

Figure 1. Results of the removal of $\mathrm{Zn}$ during the pilot phase.

hour HRT was possibly due to the high evapotranspiration at that time. This is in contrast with the other measures of HRTs which caused a concentration of HMs in the wetland and a decrease in removal percentage. During the 72 hour HRT, the best $\mathrm{Zn}$ removal efficiencies were obtained in the experimental units with the plant species Eleocharis cellulosa, having a 92\% removal in the EU 1 with FG and $91 \%$ removal in the EU 5 with coarse gravel (CG).

Finally, in the 96 hour HRT a $96 \%$ removal of $\mathrm{Zn}$ in the EU 6 which contained the plant species Typha domingensis Pers. with CG was obtained and the lowest removal efficiency was achieved in the EU 2 with the species plant Typha domingensis Pers. with FG.

The results obtained in this paper about $\mathrm{Zn}$ removal efficiencies employing a 96 hour HRT were higher than other studies. A study in Argentina which assessed the feasibility of treating industrial wastewater within a small scale constructed wetland got an average removal efficiency of $\mathrm{Zn}$ of 59\% [26]. In Flanders, Belgium, a study evaluated a HSSF-CW to treat domestic wastewater and obtained an $85 \%$ of removal efficiency of $\mathrm{Zn}$ [27]. Finally, Yeh et al. [28] evaluated three surface flow wetland systems in Taiwan and obtained a $92 \% \mathrm{Zn}$ removal rate in constructed wetlands.

\subsection{Removal Efficiencies of $\mathrm{Cu}$}

Figure 2 shows the obtained removal of $\mathrm{Cu}$ from the $\mathrm{EU}$ considering a combination of different factors like type of plant species, different size of filter media and HRT employed.

For the 24 hours HRT, the highest removal percentage of $\mathrm{Cu}(94 \%)$ was obtained in unit 2 with the species $T y$ pha domingensis Pers. and FG. The lower removal percentage was $50 \%$ in the EU 3 which was considered as the control with FG and without plants.

In the 48 hour HRT, $88 \%$ removal of $\mathrm{Cu}$ in the EU 5 with a media size filter of $5 \mathrm{~mm}$ and plant species Eleocharis cellulose was obtained. The lowest percentage of removal (58\%) was found in the EU 6 with the combination of Typha domingensis Pers. and CG.

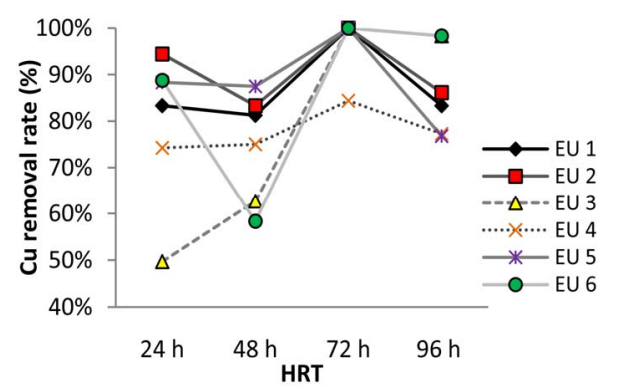

Figure 2. Results of the removal of $\mathrm{Cu}$ during the pilot phase.

During the 72 hour HRT, a value very close to $100 \%$ removal of $\mathrm{Cu}$ in almost all experimental units was obtained except for the EU 4 (86\%) which contained CG and without plants.

The 96 hour HRT reached $98 \%$ removal of $\mathrm{Cu}$ in the EU 3 and 6. The lowest removal (77\%) was achieved in the control with CG and EU 5 and with the plant species Eleocharis cellulosa with CG.

\subsection{Effect of Hydraulic Retention Time}

The optimum HRT obtained for removal of $\mathrm{Zn}$ was at 96 hours and with respect to $\mathrm{Cu}$ the highest removal efficiency was obtained in the HRT of 72 hours. These results were verified employing a statistical analysis which indicated that different hydraulic retention times employed have a statistically significant effect between the median removal efficiencies for both metals with $95 \%$ confidence, since the p-values $(0.00413157)$ and ( 0.000553874$)$ were lower than 0.05 for both HMs.

\subsection{Effect of Planted Species}

Applying a difference between the results obtained of percentage removal for the experimental units that contained the same gravel size as the experimental units employed as control, it is possible to know the influence of plants on the percentage removal of HMs. These results are shown in Figures $\mathbf{3}$ and $\mathbf{4}$.

In Figures $\mathbf{3}$ and $\mathbf{4}$ it is shown that during the 24 and 48 hour HRT there is a remarkable influence of the plants on the removal of both metals. When HRT was increased, the influence of plants for HMs retention was reduced. That could point out that an adsorption process is occurring by the plants to retain metals, but the assimilation of metals is not taking place. In addition, previous research has demonstrated a high accumulation of HMs in roots (underground) in contrast with the concentration accumulated in the leaves and stems (aboveground) [26-28].

In this aspect, Maine et al. [26] evaluated a combination of two plant species, Typha domingensis Pers and E. 


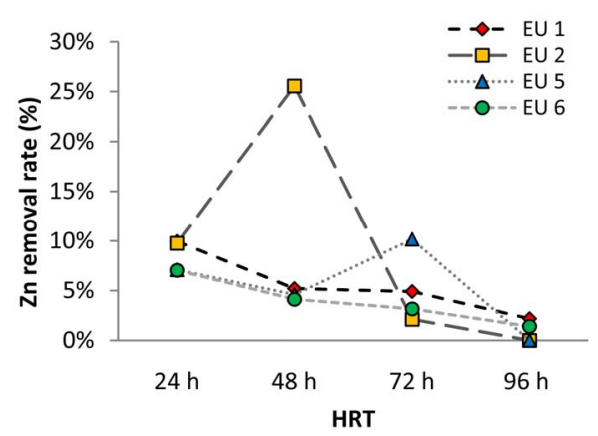

Figure 3. Influence of plant species in the removal of $\mathrm{Zn}$.

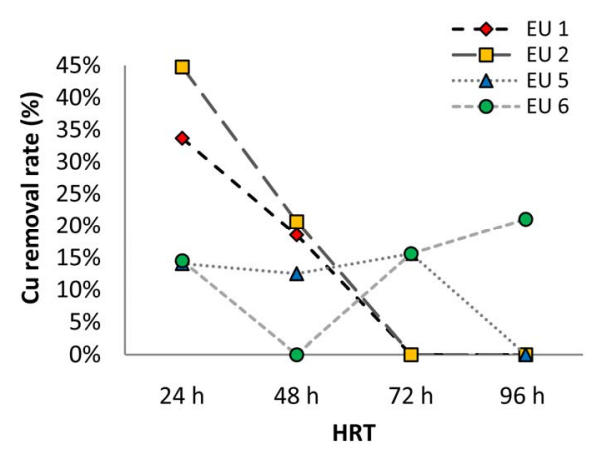

Figure 4. Influence of plant species in the removal of $\mathrm{Cu}$.

crassipes (water hyacinth) in a FWS wetland to treat effluent from a metallurgic industry. They measured the concentration of $\mathrm{Zn}$ in roots and leaves of plants after 1 year of operation. It was found that the root of Typha domingensis Pers. accumulated a concentration of 69 $\mu \mathrm{g} / \mathrm{g}$ with respect to the initial $(60 \mu \mathrm{g} / \mathrm{g})$ and final (129 $\mu \mathrm{g} / \mathrm{g}$ ) concentration. As for $\mathrm{Zn}$ accumulated in the root of the plant species E. crassipes, the values obtained were lower in the final concentration $(15 \mu \mathrm{g} / \mathrm{g})$ with respect to the starting concentration $(35 \mu \mathrm{g} / \mathrm{g})$. Therefore, this explains that roots of E. crassipes were not able to assimilate the metal. Finally, the leaves of both plant species were not able to assimilate the $\mathrm{Zn}$ because the concentration of $\mathrm{Zn}$ obtained in the leaves at the end of period was lower than initial concentration.

Moreover Liu et al. [15] investigated the accumulation of $\mathrm{Cd}, \mathrm{Pb}$ and $\mathrm{Zn}$ in 19 different plant species in a smallscale constructed wetland in Changzhou, China. They added artificial wastewater with a concentration of $\mathrm{Cd}$, $\mathrm{Pb}$ and $\mathrm{Zn}$ of $0.5,2.0$ and $5.0 \mathrm{mg} / \mathrm{L}$, respectively. The accumulated concentration of HMs in the under-ground part, aboveground part and the whole plant was different among 19 species of plants. A removal efficiency of over $90 \%$ of the metals in the wetland was obtained. The accumulated percent of HMs in plants was $19.85 \%$ of $\mathrm{Cd}$, $22.55 \%$ of $\mathrm{Pb}$ and $23.75 \%$ of $\mathrm{Zn}$ with respect to the concentration added to water initially. This explains that plant species selected to be used in constructed wetlands will influence removal efficiency of HMs from wastewater and the operation of the wetland system.

\subsection{Effect of Filter Media Size}

There are few studies that have assessed together the characteristics of different sizes and types of filter media in constructed wetland.

Kröpfelová et al. [18] employed three HSSF-CWs with the plant species Phragmites phalaris to evaluate the influence of filter media size in the removal of $\mathrm{Zn}$ and $\mathrm{Cu}$ from municipal wastewater for a period of 2 years. The authors employed three different CWs. The first wetland, called Břehov, contained gravel of $4-8$ $\mathrm{mm}$ filter media and the percent of removal was $86 \%$ for $\mathrm{Zn}$ and $84 \%$ for $\mathrm{Cu}$. The second wetland, called Mořina, contained crushed rock of $4-8 \mathrm{~mm}$ and the percent of removal obtained was $90.5 \%$ for $\mathrm{Zn}$ and $73.8 \%$ for $\mathrm{Cu}$. Finally, the third wetland, called Slavošovice, contained gravel of $3-20 \mathrm{~mm}$ and reached $58.3 \%$ and $41.7 \%$ removal for $\mathrm{Zn}$ and $\mathrm{Cu}$, respectively. Kröpfelová et al. [18] obtained higher removal efficiencies in the CWs with finer gravel, but they did not explain if they used statistical methods to obtain the influence of gravel size with respect to the removal percentage.

In this paper, particle size of filter media had no statistically significant difference with respect to percentage of removal for both HMs, but the greater averages were recorded with the fine gravel of $5 \mathrm{~mm}$ such as the results obtained by Kröpfelová et al. [18].

By comparing the results obtained for removal of $\mathrm{Zn}$ and $\mathrm{Cu}$ in this paper employing a gravel size of $5 \mathrm{~mm}$ and the results shown by Kröpfelová et al. [18] corresponding to the size of gravel of $4-8 \mathrm{~mm}$, we can see that both results were very satisfactory. However, in this paper, the results obtained in the CWs with filter media size of $15 \mathrm{~mm}$ were higher than obtained by Kröpfelová et al. [18] in the wetland that contained a gravel size of 3 $-20 \mathrm{~mm}$.

Therefore, constructed wetlands with the finer filter media allowed for retention of metals more effectively because the empty spaces between stacked gravel are smaller. According to Grambrell [21], fine textured soils containing an appreciable organic matter content tend to accumulate contaminants; nevertheless, they create a clogging effect in less time because retained solids are higher in comparison with the retained solids in a coarse gravel.

\section{Conclusions}

Over $50 \%$ of the samples analyzed for $\mathrm{Zn}$ and $\mathrm{Cu}$ from swine wastewater during characterization were above the permitted limits of NOM-001-ECOL-1996.

Comparing systems with vegetation and without vege- 
tation, there was a considerably greater efficiency in the removal of $\mathrm{Zn}$ and $\mathrm{Cu}$ in the experimental units with plants.

Considering the four different HRT employed during the pilot phase, 24, 48, 72 and 96 hours, higher removal efficiency was achieved in the HRT 96 hours for $\mathrm{Zn}$ and in the case of $\mathrm{Cu}$ the highest efficiency was recorded in the HRT of 72 hours. Therefore, HRT is a factor to take into account in order to achieve the desired removal.

Although, the particle size of filter media had no statistically significant difference with respect to the percentage of removal of metals. Greater averages were recorded with the fine gravel of $5 \mathrm{~mm}$.

The results of this research indicated that CWs could be a very useful tool for the removal of HMs like $\mathrm{Zn}$ and $\mathrm{Cu}$ in swine wastewater.

\section{Acknowledgements}

This research was part of a project denominated "Integration of biotechnological processes for the sustainable management of wastewater swine industry" and was supported financially by CONACYT and Fondos Mixtos Yucatán.

\section{REFERENCES}

[1] G. Rodríguez and L. del Moral, "Perspectivas del Sector Porcícola Mexicano para 2010: Recuperación de los Efectos de la Crisis Económica de la Influencia (A) H1/N1," Revista Trimestral de Análisis de Coyuntura Económica, Vol. 3, No. 2, 2010, pp. 21-23.

[2] SAGARPA, "Anuario Estadístico de la Producción Pecuaria de los Estados Unidos Mexicanos, Servicio de Información y Estadística Agroalimentaria y Pesquera," 2009.

http://www.siap.gob.mx/index.php?option=com_content $\&$ view $=$ article \&id=261\&Itemid $=429$

[3] R. Méndez, E. Castillo, E. Vázquez, O. Briceño, V. Coronado, R. Pat and P. Garrido "Estimación del Potencial Contaminante de las Granjas Porcinas y Avícolas del Estado de Yucatán," Ingeniería, Vol. 13, No. 2, 2009, pp. 13-21.

[4] A. Drucker, R. Semerena, V. González and S. Rueda, "La Industria Porcina en Yucatán: Un Análisis de la Generación de Aguas Residuales," Revista Latinoamericana de Economía, Vol. 34, No. 135, 2003, pp. 105-124.

[5] V. M. Alcocer, A. F. Castellanos, F. Herrera, L. A. Chel and D. A. Betancur, "Detección de Metales Pesados y Dicloro Difenil Tricloro Etano (DDT) en Músculos y Órganos de Bovinos en Yucatán," Técnica Pecuaria de México, Vol. 45, No. 2, 2007, pp. 237-247.

[6] I. Covarrubias, F. Gómez and C. Robles, "Factibilidad Técnico-Económica para el Aprovechamiento Integral de Sólidos Recuperados de Estiércol de Cerdo Fermentados en la Nutrición del Cerdo. Estiércol de Cerdo: Un Recurso Renovable,” In: L. Kato, Ed., La Producción Porcícola en México: Contribución al Desarrollo de una Visión Integral, Universidad Autónoma Metropolitana, México, 1995, pp. 21-41.

[7] R. Pérez and J. Pacheco, "Vulnerabilidad del Agua Subterránea a la Contaminación de Nitratos en el Estado de Yucatán," Ingeniería, Vol. 8, No. 1, 2004, pp. 33-42.

[8] J. Paat, "Diseño de un Sistema de Lagunas de Oxidación de las Aguas Residuales Porcícolas de Hampolol, Campeche," Tesis de Maestría, Universidad Autónoma de Campeche, México, 2002.

[9] X. Domènech and J. Peral, "Química Ambiental de Sistemas Terrestres,” Reverté, Barcelona, España, 2006.

[10] J. Vymazal, "The Use of Constructed Wetlands with Horizontal Sub-Surface Flow for Various Types of Wastewater," Ecological Engineering, Vol. 35, No. 1, 2009, pp. 117. doi:10.1016/j.ecoleng.2008.08.016

[11] J. Vymazal, "Removal of Nutrients in Various Types of Constructed Wetlands," Science of the Total Environment, Vol. 380, No. 1-3, 2007, pp. 48-65. doi:10.1016/j.scitotenv.2006.09.014

[12] C. H. Sim, M. K. Yusoff, B. Shutes, S. C. Ho and M. Mansor, "Nutrient Removal in a Pilot and Full Scale Constructed Wetland, Putrajaya City, Malaysia," Journal of Environmental Management, Vol. 88, No. 2, 2008, pp. 307-317. doi:10.1016/j.jenvman.2007.03.011

[13] J. Vymazal and L. Kröpfelová, "Removal of Organics in Constructed Wetlands with Horizontal Sub-Surface Flow: A Review of the Field Experience," Science of the Total Environment, Vol. 407, No. 13, 2009, pp. 3911-3922. doi:10.1016/j.scitotenv.2008.08.032

[14] K. Sleytr, A. Tietz, G. Langergraber and R. Raimund, "Investigation of Bacterial Removal during the Filtration Process in Constructed Wetlands," Science of the Total Environment, Vol. 380, No. 1-3, 2007, pp. 173-180. doi:10.1016/j.scitotenv.2007.03.001

[15] J. Liu, Y. Dong, H. Xu, D. Wang and J. Xu, “Accumulation of $\mathrm{Cd}, \mathrm{Pb}$ and $\mathrm{Zn}$ by 19 Wetland Plant Species in Constructed Wetland," Journal of Hazardous Materials, Vol. 147, No. 3, 2007, pp. 947-953. doi:10.1016/j.jhazmat.2007.01.125

[16] J. Vymazal and L. Kröpfelová, "Wastewater Treatment in Constructed Wetlands with Horizontal Sub-Surface Flow," Springer, Czech Republic, 2008. doi:10.1007/978-1-4020-8580-2

[17] P. E. Lim, K. Y. Mak, N. Mohamed and A. M. Noor, "Removal and Speciation of Heavy Metals along the Treatment of Wastewater in Subsurface-Flow Constructed Wetlands," Water Science and Technology, Vol. 48, No. 5, 2003, pp. 307-313.

[18] L. Kröpfelová, J. Vymazal, J. Štvehla and J. Štíchová, "Removal of Trace Elements in Three Horizontal SubSurface Flow Constructed Wetlands in the Czech Republic," Environmental Pollution, Vol. 157, No. 4, 2009, pp. 1186-1194. doi:10.1016/j.envpol.2008.12.003

[19] A. S. Sheoran and V. Sheoran, "Heavy Metal Removal Mechanism of Acid Mine Drainage in Wetlands: A Critical Review," Minerals Engineering, Vol. 19, No. 2, 2006, pp. 105-116. doi:10.1016/j.mineng.2005.08.006 
[20] D. J. Walker and S. Hurl, "The Reduction of Heavy Metals in a Stormwater Wetland," Ecological Engineering, Vol. 18, No. 4, 2002, pp. 407-414. doi:10.1016/S0925-8574(01)00101-X

[21] R. P. Gambrell, "Trace Metals in Wetland: A Review," Journal of Environmental Quality, Vol. 23, No. 5, 1994, pp. 883-881. doi:10.2134/jeq1994.235883x

[22] U. Stottmeister, A. Wießner, P. Kuschk, U. Kappelmeyer, M. Kästner, O. Bederski, R. A. Müller and H. Moormann, "Effects of Plants and Microorganisms in Constructed Wetlands for Wastewater Treatment," Biotechnology Advances, Vol. 22, No. 1-2, 2003, pp. 93-117. doi:10.1016/j.biotechadv.2003.08.010

[23] APHA, "Standards Methods for the Examination of Water and Wastewater," 21st Edition, American Public Health Association, Washington DC, 2005.

[24] D. C. Montgomery, "Diseño y Análisis de Experimento," Limusa, México, 2008.

[25] SEMARNAT, "Norma Oficial Mexicana NOM-001ECOL-1996, Que Establece los Límites Máximos Permisibles de Contaminantes en las Descargas de Aguas Residuales en Aguas y Bienes Naciones," Secretaría de Medio Ambiente, Recursos Naturales y Pesca, Diario Oficial de la Federación, 1996.

[26] M. A. Maine, N. Suñe, H. Hadad, G. Sánchez and C. Bonetto, "Nutrient and Metal Removal in a Constructed
Wetland for Wastewater Treatment from a Metallurgic Industry," Ecological Engineering, Vol. 26, No. 4, 2006, pp. 341-347. doi:10.1016/j.ecoleng.2005.12.004

[27] E. Lesage, D. P. L. Rousseau, E. Meers, F. M. G. Tack and N. De Pauw, "Accumulation of Metals in a Horizontal Subsurface Flow Constructed Wetland Treating Domestic Wastewater in Flanders, Belgium," Science of the Total Environment, Vol. 380, No. 1-3, 2007, pp. 102-115. doi:10.1016/j.scitotenv.2006.10.055

[28] T. Y. Yeh, C. C. Chou and C. T. Pan, "Heavy Metal Removal within Pilot-Scale Constructed Wetlands Receiving River Water Contaminated by Confined Swine Operations," Desalination, Vol. 249, No. 1, 2009, pp. 368373. doi:10.1016/j.desal.2008.11.025

[29] F. Tapia, G. Giácoman, J. Herrera, C. Quintal, J. García and J. Puigagut, "Treatment of Swine Wastewater with Subsurface-Flow Constructed Wetlands in Yucatán, Mexico: Influence of Plant Species and Contact Time," Water SA, Vol. 35, No. 3, 2009, pp. 355-342.

[30] Q. Xian, L. Hu, H. Chen, Z. Chang and H. Zou, "Removal of Nutrients and Veterinary Antibiotics from Swine Wastewater by a Constructed Macrophyte Floating Bed System," Journal of Environmental Management, Vol. 91, No. 12, 2010, pp. 2657-2661. doi:10.1016/j.jenvman.2010.07.036 